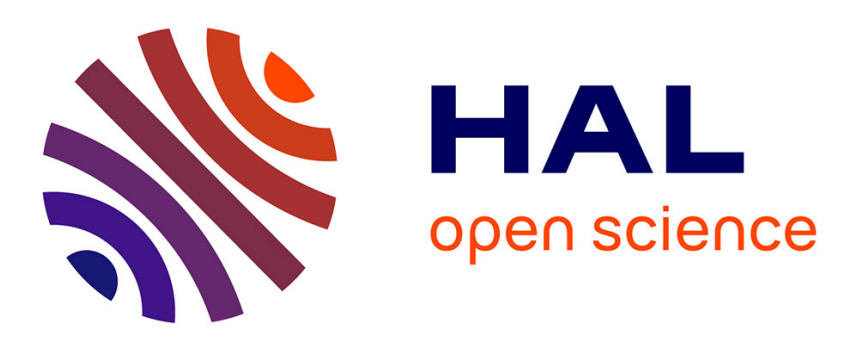

\title{
A Previously Unpublished Correspondence between Adam Smith and Joseph Nicolas de Windischgrätz
}

\author{
José M Menudo, Nicolas Rieucau
}

\section{To cite this version:}

José M Menudo, Nicolas Rieucau. A Previously Unpublished Correspondence between Adam Smith and Joseph Nicolas de Windischgrätz. History of Political Economy, 2017, 49 (1), pp.93-112. 10.1215/00182702-3777170 . hal-01615077

\section{HAL Id: hal-01615077 \\ https://hal.science/hal-01615077}

Submitted on 13 Oct 2017

HAL is a multi-disciplinary open access archive for the deposit and dissemination of scientific research documents, whether they are published or not. The documents may come from teaching and research institutions in France or abroad, or from public or private research centers.
L'archive ouverte pluridisciplinaire HAL, est destinée au dépôt et à la diffusion de documents scientifiques de niveau recherche, publiés ou non, émanant des établissements d'enseignement et de recherche français ou étrangers, des laboratoires publics ou privés. 


\section{A PREVIOUSLY UNPUBLISHED CORRESPONDENCE BETWEEN}

\section{AdAM SMITH AND JOSEPH NiCOLAS DE WINDISCHGRÄTZ*}

\section{José M. Menudo and Nicolas Rieucau}

"I wrote $[\ldots]$ to Mr Smith as a precautionary measure", states the count of Windischgrätz to Condorcet in a letter dated May $9^{\text {th }} 1785 .{ }^{1}$ In order to take steps to prevent the refusal of the Royal Society of London to judge the replies to the prize he had proposed on the unification of property transfers, Windischgrätz indeed wrote to Smith to encourage him to present his project to the Royal Society of Edinburgh. ${ }^{2}$ Written "as a precautionary measure", this letter from Windischgrätz to Smith represents, however, the beginning of a rather rich and lengthy exchange - which would end at the beginning of 1788 - composed of at least sixteen pieces. ${ }^{3}$

Written by Windischgrätz to Smith, five of these letters are not known to have survived; their existence can be deduced by reading the other pieces. ${ }^{4}$ Ross and Raynor (1997),

* Correspondence may be addressed to José-Manuel Menudo at jmmenpac@upo.es and to Nicolas Rieucau at nicolas.rieucau@univ-paris8.fr. We would like to thank Emmanuelle de Champs and Jakub Mirka for her comments and suggestions on an earlier version of this article. The paper benefited from inspiring remarks made by two anonymous referees and the editor of this journal. Any remaining errors are nevertheless our responsibility.

${ }^{1}$ SRAP, WFA, n¹564 (unnumbered piece, our translation).

${ }^{2}$ See Grecenkova (2003) for a lengthy commentary about this prize.

${ }^{3}$ The list is provided in infra, p. 19.

${ }^{4}$ See ibid. We point out that Smith never received some letters. In this regard, on December $16^{\text {th }} 1787$, he wrote to Windischgrätz: "Your letter from Prague has never come to my hand", infra, letter n4, p.17. Windischgrätz replied on December $30^{\text {th. }}$ "It is incredible that my letters get lost so often, especially when I write to people to whom, like yourself, I absolutely want them to arrive", Windischgrätz to Smith, in Ross \& Raynor (1997, 185, our translation). 
however, published eight letters, of which we have previously cited one to Smith in May 1785. We would like to complete this research by publishing four letters. Three of these are from a set of manuscripts conserved in the State Regional Archives in Plzen, Czech Republic, within the Windischgrätz family papers. ${ }^{5}$ We already knew of one of these three letters through a copy - conserved in Aldourie Castle in Inverness - published by Ross and Raynor (1997, 179-182), while we later transcribed the original version. The two remaining letters have never before been published. A fourth letter, also unpublished, was sold in June 2015 in Vienna by the Dorotheum auction house. ${ }^{6}$

As with the rest of the correspondence between Smith and Windischgrätz, the letters published here refer to the prize proposed by Windischgrätz on the unification of property transfers. The Programme of this prize was initially published in German in 1784, in Latin the following year, and in an expanded version, in French. The problem set out consisted of:

"finding in all possible types of writings through which [his property] could be transferred [...], general formulas constructed in such a way that it is sufficient to fill in the blank spaces to express each particular case, $[\ldots]$ therefore both variable and invariable expressions, that is, the entire statement, leave as little room for doubt and interpretations as geometry."7

In the body of the text of his Programme, Windischgrätz describes the challenge more completely:

"Those who feel disposed to undertake this task must perform three different operations: $1^{\circ}$. The classification of all possible situations in which property can be transferred, $[\ldots] 2^{\circ}$.

${ }^{5}$ SRAP, WFA, n931. This manuscript escaped Ross \& Raynor’s research. In fact, its editing is only based on papers with shelf mark SRAP, WFA, n 1464.

${ }^{6}$ Palais Dorotheum, June $1^{\text {st }} 2015$, Autographs, lot n85 (expert Andreas Löbbecke). We do not know where this letter is currently located.

${ }^{7}$ Windischgrätz (1785, title page). 
The construction of the formulas, $3^{\circ}$. The demonstration that the Problem can in fact be solved. The first of these operations is the only one of which one may doubt; it is the most metaphysical part of the work, that which involves a greater number of ideas [...], it is to determine to what, finally, are reduced all of the situations that might arise before a man on transferring his property [...] [.]. [T]he second operation [must be] applicable to all possible particular cases $[\ldots]$. Perhaps $[\ldots]$ it consists only of imagining formulas for a certain number of simple cases, [...] and by combining them to create forms for all of the cases; as ten numbers are sufficient to express all the possible quantities. The demonstration that the Problem can, in effect, be solved will not be difficult once the first two operations have been well done". 8

Of the scientists to whom Windischgrätz presented this political arithmetic problem, it was Condorcet who showed the most enthusiasm. ${ }^{9}$ The latter was, in fact, a fervent promotor of the application of mathematics to other areas of human knowledge, for which he would attempt to create a methodological synthesis through his social mathematic programme. ${ }^{10}$ Moreover, the plan to establish "general formulas" for property transfer matched his own reflections on the establishment of a universal language. ${ }^{11}$ Condorcet would help

\footnotetext{
${ }^{8}$ Ibid., p. 10, 12 our translation).

${ }^{9}$ Regarding this issue, see Grecenkova (2006), (2007), (2009). However, these three works are very redundant — some entire passages are identical — and additionally, they are based on correspondence between Condorcet and Windischgrätz with incorrect dates and shelf marks. Before Grecenkova's works, the interest shown by Condorcet in Windischgrätz's Programme was noted by Baker (1975, 226-227), Daston (1988, 347), Bru \& Crépel (1994, 530-535).

${ }^{10}$ See Crépel \& Rieucau (2005).

${ }^{11}$ See Condorcet to Windischgrätz (March $26^{\text {th }}$ 1785), SRAP, WFA, nº 1562 , f. 2 r, and Condorcet (October $9^{\text {th }} 1785$, p. 535).
} 
Windischgrätz to translate his Programme into French, ${ }^{12}$ he would promote the prize in the Journal de Paris ${ }^{13}$ and he would actively help the Austrian count to find scientific societies that could be judges of the responses to the prize. Precisely, Condorcet would obtain consent from the Académie des science de Paris ${ }^{14}$ and from the University of Basel, ${ }^{15}$ while Windischgrätz would obtain that of the Royal Society of Edinburgh with the mediation of Smith.

Dated June $20^{\text {th }} 1785$, the first letter that we publish, written by Windischgrätz to Smith, mentions three main points: the circulation of the French version of Windischgrätz's Programme (French version with which the count predicts he will respond to some of Smith's objections), the advertisement for this same Programme that he would want to disseminate in newspapers in Great Britain and, lastly, the choice of a third scientific society that would judge (with those of Paris and Edinburgh) the responses to the prize.

The second letter, written by Smith on July $4^{\text {th }} 1785$, is the one previously published by Ross and Raynor (1997, 179-182) based on copy. The version published here is based on the original letter and conforms to the editorial conventions of the Glasgow edition of The Correspondence of Adam Smith (1977). It varies from Ross and Raynor's version in some forty places (mostly with respect to spelling). Although the Royal Society of Edinburgh had

\footnotetext{
${ }^{12}$ See Condorcet to Windischgrätz (June $9^{\text {th }} 1785$ ) and (second fortnight of June 1785), SRAP, WFA, respectively $\mathrm{n}^{\circ} 1562$, f. $5 \mathrm{r}$ and $\mathrm{n}^{\circ} 959$, file $\mathrm{n}^{\circ}$ XIII, f. $5 \mathrm{r}$-v, and Corrections sur la traduction française $d u$ Programme de Windischgrätz (June 1785), SRAP, WFA, nº59, file nº XIII (unnumbered sheets).

${ }^{13}$ Condorcet (1785). Bru \& Crépel (1994, 534-535) have shown that this anonymous text was by Condorcet, since the manuscript of this text handwritten by him has been found.

${ }^{14}$ See Condorcet to Windischgrätz (March 26 $6^{\text {th }} 1785$ ), (April $6^{\text {th }} 1785$ ) and (April 18 $18^{\text {th }} 1785$ ), respectively SRAP, WFA n ${ }^{\circ}$ 1562, f. 1 r-v, f. 3 r and f. 4 r. Handwritten by Condorcet and also signed by Borda, Duséjour and Laplace, the favourable Rapport (April 30 $0^{\text {th }} 1785$ ) from the French Academy of Sciences was published by Bru \& Crépel (1994, 532-534).

${ }^{15}$ See Condorcet to Windischgrätz (August $18^{\text {th }} 1786$ ), SRAP, WFA, nº1562, f. 28 r-v.
} 
agreed to judge the responses to the prize, in this letter Smith questions the relevance of the subject proposed by Windischgrätz. Effectively, he does not think that it is possible to establish, even approximately, "general formulas" to describe the contractual rules of property transfers. As Ross \& Raynor $(1997,174)$ explain, "he countered the Leibniz-Condorcet rationalist type of thinking in Windisch-Grät'z proposal by presenting [...] a characteristic line of empirical, realistic reasoning about legal conflicts". ${ }^{16}$ In this regard, Smith invokes the idiosyncrasy of contractors - according to him, the source of innumerable situations which burden property transfers - and the particular national laws; he suggests to Windischgrätz a reform limited to the "Style Books" of his country. ${ }^{17}$ The letter ends with Smith's response to Windischgrätz's two proposals. First, Smith declines to urge colleagues at the Royal Society of Edinburgh to accept compensation for their collaboration in the judgment of responses to the prize since, he says, this contribution will not be difficult. Secondly, Smith refuses to help Windischgrätz by advertising the prize in newspapers in Great Britain because, according to him, the distribution of the Programme is sufficient to the need.

Dated September $14^{\text {th }} 1785$, the third letter is a reply to the previous letter. Windischgrätz wholly rejects Smith's objections. Making reference to certain passages in his French Programme, the count's reply is mainly methodological. According to him, the national or psychological circumstances do not need to be reflected upon a priori, but a general classification needs to be built at the outset, abstractly considering all possible cases, which he

\footnotetext{
${ }^{16}$ Smith deals with property transfers in his Lectures on Jurisprudence (1762-1763, 71). Indeed, Smith explains why the uncertainty of language is one the reasons which would hinder contracts from sustaining action and how the first contracts which were binding were conceived in "a certain set form of words, called stipulationes" (ibid., 89).

${ }^{17}$ For more information on Smith's critique, see the comment and note of this letter in Ross \& Raynor (1997, 174-175, 179-182). There are also some explanations in Ross (2010, 393-394).
} 
consequently considers, unlike Smith, countable. Only in a second phase is it applied to one or another country, therefore coinciding with a reduction in the number of possible cases.

The last letter that we are publishing, written by Smith on December $16^{\text {th }} 1787$, is related to the decision, by the Royal Society of Edinburgh, of the responses to Windischgrätz's competition. Smith, member of the committee in charge of the resolution, informed Windischgrätz of the delay caused in the resolution because he would have to be away from Edinburgh for some time on a visit to Glasgow - without revealing to Windischgrätz that the reason for this visit was his new position as Lord Rector of the University of Glasgow.

Three pieces that endeavoured to respond to Windischgrätz's Programme were evaluated, but none of them would receive the prize. The negative judgment of the Royal Society of Edinburgh was announced on January $21^{\text {st }} 1788,{ }^{18}$ that of the University of Basel at the beginning of March $1788^{19}$ and, lastly, that of the French Academy of Sciences on February $7^{\text {th }} 1789 .{ }^{20}$ However, one of the pieces, written in Latin, was deemed to have some merit. ${ }^{21}$

When Smith wrote to Windischgrätz on January $26^{\text {th }} 1788$ to inform him of the judgment from the Royal Society of Edinburgh, he made the most of the opportunity to ask him to continue the correspondence with Alexander Fraser Tytler, secretary of the Scottish

\footnotetext{
${ }^{18}$ Transactions of the Royal Society of Edinburgh, Vol. II, 24.

${ }^{19}$ The exact date is unknown. We have estimated a date from the content of a letter from Condorcet to Windischgrätz (March 13 $3^{\text {th }} 1788$ ), SRAP, WFA, $n^{\circ} 1464$, piece n²8, f. 1 r.

${ }^{20}$ See the Extrait des registres de l'Académie royale des sciences du 7 février 1789 sent by Condorcet to Windischgrätz, SRAP, WFA, nº31 (unnumbered piece). Ross \& Raynor $(1997,175)$ state that they did not find this document. As we have indicated supra, n. 5, their research was limited to those manuscripts with shelf mark SRAP, WFA, nº1464.

${ }^{21}$ We are only aware of this piece by its motto, taken from Horace, and quoted for example in the Extrait des registres de l'Académie royale des sciences du 7 février 1789: "If you know better pass it on; if not, make use of the above with me." (our translation). SRAP, WFA, n'931 (unnumbered piece).
} 
institution $^{22}$. To justify himself, Smith would specifically invoke health reasons and numerous occupations. But in general, as Ross points out (1974, vii), "Smith for the most part was a perfunctory, dilatory correspondent". From this point of view, it is not surprising that the body of his active (and passive) correspondence published to date is relatively small: since the Glasgow edition (1977), which barely comprises more than 300 letters, only fifteen pieces, to our knowledge, have been published; eight of these were exchanged between Smith and Windischgrätz. ${ }^{23}$ From this point of view, we consider the publication of new pieces, within this correspondence, to be very valuable.

\section{$\underline{\text { Editorial conventions }}$}

We follow the editorial conventions described by Ross in the "preface" (p. ix) of the Glasgow edition of The Correspondence of Adam Smith (1977). Written in French, both of Windischgrätz's letters have been translated in English. The French original can be found in appendix A.

Letter $n^{\circ} 1$ : Windischgrätz to Smith, June $20^{\text {th }} 1785$, SRAP, WFA, $n^{\circ} 931$, piece $n^{\circ} 36$

Brussels, 20 June 1785

Sir

\footnotetext{
${ }^{22}$ Smith's letter of January 26, 1788, was published by Ross \& Raynor (1997, 186-187).

${ }^{23}$ In addition to Ross \& Raynor (1997), see Dow (1984), Raphael et al. (1990) and Lock (2006).
} 
I must begin by excusing myself for writing to you always in French. For although I know enough English to understand the letters that you do the honour of writing to me, I do not know sufficient to write it myself.

I have no doubt, Sir, that my reply of 7 June to the letter you did the honour of writing to me on 27 May will arrive, ${ }^{24}$ but as my business requires me, from these first days of July, to visit my lands in Bohemia and Germany ${ }^{25}$, and, necessarily, I must publish, before me departure from here, my programme in French with the additions which appear to me to clarify very well the subject, ${ }^{26}$ you will pardon me, I hope that it be so, Sir, if, instead of awaiting your reply to my last [letter], I take the liberty of addressing you once more to ask you :

1) What must I do to send you, from here, safely and in a manner in which the cost of transport falls solely on myself, fifty copies in French of my programme?

2) What must I do to print, translated into English, the announcement found at the end of this letter in some newspapers in Great Britain? ${ }^{27}$

Allowing the booksellers of London and Edinburgh to keep the proceeds from the copies in Latin, which Mr. Mathews still has in his possession and which I would instruct him to

${ }^{24}$ Smith's letter of May 27 1785 was edited by Ross \& Raynor (1997, 178-179). Moreover, that of Windischgrätz dated June $7^{\text {th }} 1785$ has not been found; it is likely that Smith never received it because, to our knowledge, he makes no reference to it in his letters to Windischgrätz, while the latter, after getting somewhat exasperated for not having received a reply (see the end of this paragraph), ends by asking if Smith had received the letter (see Windischgrätz to Smith, July 12 ${ }^{\text {th }} 1785$, in Ross \& Raynor 1997, 182).

${ }^{25}$ In Tachov, Czech Republic, and Vienna, respectively. At the time, both cities formed part of the Holy Roman Empire.

${ }^{26}$ See Windischgrätz (1785).

${ }^{27}$ Only the incipit of this announcement, written in French, appears at the end of the present document (which is a copy of the original letter prior to being sent). The whole text has not been found. Its printed English version never existed because Smith considered it useless to circulate it. See infra, letter $\mathrm{n}^{\circ}$ 3, p. 13. 
deliver to them, I believe that the booksellers could, at their own cost, arrange to translate and print this announcement in the newspapers. ${ }^{28}$ Be so kind as to tell me, Sir, I pray, what you think in this respect.

3) If you accept the agreement which I have taken the liberty of proposing to you, that is, if the Royal Society of Edinburgh agrees, as I eagerly hope and desire, to take part in the judgement, which I have offered to it through you, Sir, in that case, I say that it would be to you indifferent whether it should choose one or another Academy in Germany to take part in this judgement with you, Sirs, and with the Academy of Sciences of Paris, of whose consent I am sure. For I must warn you that the Academy of Berlin does not wish to participate in this judgement; ${ }^{29}$ but as it will not be difficult to replace it with another German or, in all events, a Swiss Academy, and as it is sufficient to name the Royal Society of Edinburgh and the Academy of Sciences of Paris to inspire trust in those who may be tempted to work on the solution, indicating to them, at the same time, to whom they should address their writings, I can choose this third Academy at my pleasure and await, Sir, your definitive reply to my last letter, to have my programme printed, to announce it in the newspapers and to close this affair,[;] which is causing me suffering and displeasure, and which I believe a question of this nature should not cause, if I did not know that, generally, one almost always finds more obstacles on one's path when one wishes to do good than when one makes projects damaging to Society.

${ }^{28}$ Jacques Matthews was the intermediary in England to circulate the Programme in Latin; he would send Smith one hundred copies. See Grecenkova $(2002,294)$ in this regard. In July 1785 , Windischgrätz would also send 50 copies in French from Brussels to Adam Smith, who would confirm receipt of same in January 1786. See Windischgrätz to Adam Smith (July 12 $2^{\text {th }} 1785$ ) and Smith to Windischgrätz (January $17^{\text {th }} 1786$ ), in Ross \& Raynor (1997, 182-183).

${ }^{29}$ Written by Friedrich Benjamin d'Anières, the negative report from the Academy of Berlin was read in the session of June $9^{\text {th }} 1785$. See d'Anières (1785) and Sitzungsprotokolle 1746-1786, I-IV-32, Bl. 396r. 
I await impatiently, Sir, your replies and your observations on my problem, as you have promised me. ${ }^{30}$ I am sure that they will shed much light; but I feel only pride that my programme, as it is in French, perhaps clarifies some doubts that you may have harbored until now in this respect. I myself doubt that the problem will be quickly resolved, but if it is not under the terms prescribed, I shall propose it again and, perhaps, in this time we shall obtain works that, at least, will clarify to us the manner in which the proposal must be made in order to reach a complete solution.

I have the honour, Sir, of holding you in the highest regard ${ }^{31}$

A programme has been announced in different newspapers in which considerable premiums are offered for the solution of the following problem. ${ }^{32}$

\section{Letter $n^{\circ} 2$ : Smith to Windischgrätz, July $4^{\text {th }} 1785$, SRAP, WFA, $n^{\circ} 931$, piece $n^{\circ} 33$}

Sir

In a former Letter, ${ }^{33}$ which I did myself the honour to write to you, I took the liberty to suggest, that in my own private opinion, as well as in that of several of my most respectable Colleagues, the problem proposed in your programme would admit, not only of no compleat

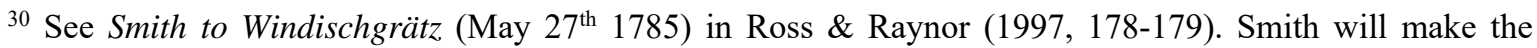
comments in question in the letter of July $4^{\text {th }} 1785$ (infra, letter $\left.\mathrm{n}^{\circ} 2\right)$.

${ }^{31}$ It is not surprising that the end of this expression of courtesy is absent because, let us recall, the present document is a copy of the original letter prior to being sent.

32 The continuation of the text to be translated was the problem stated on the title page of Windischgrätz (1785). Regarding the topic of the statement of Windischgrätz's Programme in European newspapers, see Grecenkova $(2002,294 n)$ or $(2003,279)$.

${ }^{33}$ See Smith to Windischgrätz (May 27 $\left.7^{\text {th }} 1785\right)$, in Ross \& Raynor (1997, 178-179).
} 
solution, but of nothing which could deserve even the name of an approximation. The following are some of the reasons which dispose me to entertain this opinion.

1st I know no limit to the variety of conditions with which human vanity and caprice ${ }^{34}$ may burthen the transference of Property. Each different combination of that endless variety of conditions will require a different form of expression; because wherever the transference is burthened with two, or more conditions, the second condition may limit and alter, in many different ways, the operation of the first; and the third of the second. There are but twenty four letters in the Alphabet ${ }^{35}$, and we all know the variety of ways in which they may be combined. Human Vanity \& Caprice have surely invented, long ago, many more than twenty four different conditions, which may be annexed to the transference of property and which may be combined together in an almost infinite variety of ways.

2nd In every different Country the forms; by which property is transferred, either from the dead to the living, or from the living to the living; are necessarily dependent upon and regulated by the positive Laws of each particular Country, and vary with those laws. Hence a Contract which would be perfectly valid in France, may frequently not be valid in England; and a Testament which would be perfectly valid in England, is frequently not valid in Scotland. While the laws of different Countries are so different it seems impossible to invent a set of forms which will apply to more than one Country. Even such a set of forms can be invented only by persons perfectly skilled in the Positive laws of that particular Country. ${ }^{36}$

\footnotetext{
${ }^{34}$ Although vanity is a main element, as part of the approval mechanism in Adam Smith (McCloskey, 2008; Paganelli, 2009), and present in his main works (Ross \& Raynor, 1997, 179n), the expression "vanity and caprice", repeated in this correspondence, is absent in his publications.

${ }^{35}$ At that time, the English alphabet consisted of twenty-six letters. It is probable that Smith, following Latin spelling rules, considered "I" and " $\mathrm{J}$ " to be a single letter, and likewise "U" and "V".

${ }^{36}$ For Smith, set of positive laws never matches the system of natural justice and, moreover, the former is particular to each time and place. See Smith $(1790,341)$.
} 
3rdly There are in every country Voluminous Collections of Approved forms of writings for the transference and conveyance of property, of which some are printed and some in manuscript. These collections, which are the produce of the wisdom and experience of many successive generations, I believe to be, with all their faults (and the best that I have seen are not without many faults) much more perfect than anything which, either any single man, or any single society of men are capable of inventing. These collections are in Scotland called Style Books. ${ }^{37}$ Every practitioner of law is provided with one or more of them. If I was, however, tomorrow, to desire any experienced and able practitioner of law to prepare the form of some complex agreement, he would have no hope of finding in any of his Style books a form which so exactly expressed the meaning of the contracting parties as to leave him nothing to do, but to fill up the blanks left for the names and the dates. He would be obliged to employ his own ingenuity and to express as well as he could the meaning of the contracting parties. When he first enters upon his profession he always carefully studies and frequently transcribes his Style Book. But when he comes to practise, he considers his Style Book, in the same light in which a modern painter, considers the works of the Ancient Masters; as models for imitation; but for imitation without copying. ${ }^{38}$ If the object of your problem had been merely to improve the Style Book of your own country, and to render it more distinct, more simple, and at the same time more comprehensive, it might have produced some improvement in the local administration of Justice there. From the most generous, liberal and public spirited intentions, by aiming at a much more extensive utility, I am afraid, (you will forgive me, I hope, when I take the liberty to tell you so) you have rendered it altogether useless. May it, perhaps, not yet be too late; and may I, in the most respectful manner still presume to submit

\footnotetext{
${ }^{37}$ On Style Books, see Ford (2007, 52-59).

${ }^{38}$ As Ross \& Raynor recall $(1997,181 n)$, Smith writes a text on this matter, called On the Nature of that Imitation which takes place in what are called the Imitative Arts (published in the posthumous work Essays on philosophical subjects, 1795).
} 
the propriety of your accomodating your problem to this object, of much more humble, no doubt, but much more solid utility.

I have no hope of perswading our Society to accept of any compensation for any trouble which they may be put to upon this occasion. I have, indeed, no wish to perswade them; for, I acknowledge, I do not expect the trouble will be great. ${ }^{39}$ You will forgive me, I hope, when I take upon me to assure you that the solution of your Problem, as it stands at present; is a task which no man living is qualified to undertake; and which nobody will undertake but such as are the least qualified to do so; some ignorant, indigent and presumptuous pretenders to literature who mean nothing but to impose upon you and the public and to rob you of your money.

The french translation of your programme may be sent to me in the same manner as the latin original. We think, however, that we sufficiently understand the Latin. The distribution of your Programme will sufficiently publish your intentions without any newspaper advertisements. I never suffer my name to appear in a newspaper when I can hinder it, which, to my sorrow, I cannot always do. ${ }^{40}$ It will, I imagine be perfectly indifferent to the Society here, what societies you join them with.

${ }^{39}$ This passage responds to the reiterated proposal by Windischgrätz (which can be considered quite a clumsy move to grant the Royal Society of Edinburgh 50 Louis d'or as compensation for the time spent judging the responses to the Programme. These 50 Louis d'or would have made up the prize for another competition, freely chosen by the Scottish society. See Windischgrätz to Smith (May 10 $0^{\text {th }} 1785$ ) in Ross \& Raynor (1997, 177). Agreeing to participate in the decision, the Royal Society of Edinburgh would refuse (July $9^{\text {th }} 1785$ ), as Smith said in his letter, Windischgrätz's compensation proposal. See Transactions of the Royal Society of Edinburgh, Vol. I, 38-39.

${ }^{40}$ Ross \& Raynor $(1997,181 \mathrm{n})$ indicate in this respect that "Smith in general was a very private man who disliked reviews, and he was particularly sensitive about the adverse publicity directed by Christians against his description of David Hume as 'approaching as [near] to the idea of a perfectly wise and virtuous man, as perhaps the nature of human frailty will permit"'. Regarding this matter, also see Ross (2010, p. xxx, 323-324). 
I have many apologies to make for having delayed so long to write to you; and still more for the very great freedom with which I have written. You will, however, I hope, do me the honour to believe me to be, with the highest respect and regard Sir

Your most obedient and most Humble Servant

Adam Smith

Edinburgh

4 July 1785.

Letter $n^{\circ} 3$ : Windischgrätz to Smith, September $14^{\text {th }} 1785$, SRAP, WFA, $n^{\circ} 931$, piece n³7

[Address:] To Sir / Sr Doctor Adam / Smith one of the commissioners / subintendents of the Customs of Scotland / in Edinburgh / in Scotland

Vienna, 14 September $1785^{41}$

Sir,

I have the honour to write to you from Brussels, ${ }^{42}$ when at the moment of my departure I received the letter of 4 July, ${ }^{43}$ which you did me the honour of writing to me. I can sincerely assure you, Sir, that I am touched by the kindness and frankness with which you reason about my problem, and if the journeys I have made and the occupations I have had since my

\footnotetext{
${ }^{41}$ This date and place have been added, after being written at first at the end of the letter.

${ }^{42}$ See Windischgrätz to Smith (July 12 $\left.{ }^{\text {th }} 1785\right)$, in Ross \& Raynor (1997, p. 182).

${ }^{43}$ Supra, letter $n^{\circ} 2$.
} 
departure from Brussels had not prevented it, I should not have taken until now to testify my gratitude to you.

No doubt the copies in French of my programme, which I had the honour to send to you over two months ago, will have arrived. ${ }^{44}$ Meanwhile, as the Latin was no more than a poor translation from the German, I myself have remade the programme in French, adding some reflections and some notes, which are perhaps worthy of a moment of your attention, and meanwhile I impatiently await to learn what you think of it. ${ }^{45}$

The reflections which you make, Sir, are all very profound. They demonstrate that there are great difficulties to be overcome in order to resolve my problem; but, allow me to say, Sir, that they do not show, in my view, that such difficulties are insuperable. The $\S .16$ and 20 of my programme in French, ${ }^{46}$ and some of my notes, which I have added to this edition, contain, I believe, answers to your objections.

\footnotetext{
${ }^{44}$ Regarding this matter, see supra, n. 27.

${ }^{45}$ Also see the end of the current letter, in which Windischgrätz repeats his desire to hear Smith's opinion on his Programme. Nevertheless, his desire will not be satisfied. When he confirms receipt - more than two months later ! - of the French copies of Windischgrätz's text, Smith simply says: "Whatever may be my own private opinion concerning the practicability of your problem, I beg you would be assured, that, both upon your account and upon account of the Public, nothing could make [?me] more happy than the success of it.", Smith to Windischgrätz (June $\left.17^{\text {th }} 1786\right)$, in Ross \& Raynor (1997, p. 183-184).

${ }^{46}$ See Windischgrätz (1785, respectively p. 9 and 10-13). Section XVI is about the nature of the competition, stating that it consists of creating "general formulas" and not of the range of applications that national legislation generates. Section XX describes the three parts or operations that every work must contain: (i) a classification that considers "toutes les conditions, qui peuvent passer par l'esprit de l'homme en transférant sa propriété" Windischgrätz therefore deems, unlike Smith, that these conditions are countable - (ii) the construction of general formulas, based on this classification, of different property transfers and (iii) demonstration of the two previous operations.
} 
However, let us suppose for a moment that the complete solution to my problem were impossible; should we conclude that it is not worth the endeavour to approximate? Although, in practice, it were not possible to approximate to geometrical exactness, because it cannot be achieved, would it be possible to measure the spaces? I believe there is no other way which could reduce the disputes over the words, other than that which I indicate to eliminate them.

If I were able to believe that the difficulty were much less if, instead of taking account of all the nations, I had contented myself with taking as my object a single nation or a single province, I should have taken that path with great pleasure, although it is more humble, as you very well say, $\mathrm{Sir}^{47}{ }^{47}$ than that which I have taken; but it does not seem possible to me to end the disputes over the words, not even in a single nation, following any path other than that which I propose. All of the cases must always be foreseen and, foreseeing them all, the problem is solved for all of the countries. It would be progress, I admit, if, at least, what you call Style books could be perfected; but if limited only to this end, be good enough to tell me, Sir, how it would be necessary to enunciate the problem to which we require the solution in order not to be inundated with works, of which the authors would believe to have solved the problem, and, therefore, whose utility would be most mediocre, almost none: the terms perfect, make more perceptible, simpler, are vague, everyone interprets them in their own manner.

When a problem to be resolved is proposed, it appears to me that, at the same time, the path must be marked that must be followed by those minded to occupy themselves with it; without that, you will receive a multitude of dissertations, none of which achieves the proposed end; for never have we prated so much as we prate today in all the countries of the world.

\footnotetext{
${ }^{47}$ Limited alteration to the Style Books of Windischgrätz's nation is precisely considered by Smith as "much more humble, no doubt, but much more solid utility" (letter n², supra, p. 10).
} 
Likewise, if the object I have prescribed is not addressed, we shall never, it appears to me, even come to perfect very much the Styles Books of a single province.

It may be that few persons have the courage to undertake the work required; but better to have no works than to have them and that they lead to nothing.

This is the way in which I see things; if you would be so good as to reflect on them, perhaps you will come closer to my point of view, and perhaps also you may make me change: in such case, I should be delighted to have been enlightened by you and, with that, to raise the recognition and the high regard in which I have the honour to hold you

Sir

${ }^{48}$ Your most humble and obedient servant The Count of Windisch-Grätz P.S. If you do me the honour of writing to me, Sir, address your letters always, I pray, to Brussels

Letter $n^{\circ}$ 4: Smith to Windischgrätz, December $16^{\text {th }} 1787$. Unknown location. Sold in Vienna- Palais Dorotheum, June $1^{\text {st }} \mathbf{2 0 1 5}$, Autographs, lot $\mathbf{n}^{\circ} 85$

[Address:] To Monsieur / Monsieur le Comte de Windish-/graff / in / Brussels [Pressed red sealing wax.]

[Several postal inscriptions can be found on the page containing this address:

\footnotetext{
${ }^{48}$ On the same line, on the left side of the page, "Vienne le 14 Sept 1785 " has been crossed out. These notes were actually positioned at the beginning of the letter.
} 
- "Maid AM" [= Maidstone Ante Meridiem?];

- Three traces of circular-shaped postmarks: "POST PAID"; “De" “19" "87" [=December $19^{\text {th }}$ $1787]$ and "DE" " 16 " [=December $\left.16^{\text {th }}\right]$;

- postal tariff "6"].

Sir

Your letter from Prague has never come to my hand: ${ }^{49}$ that from Brussels of the $9^{\text {th }}$ November, I received a few posts ago. ${ }^{50}$ It happens very unluckily that a very important piece of business obliges me to set out for Glasgow tomorrow morning: ${ }^{51}$ Otherwise the works of the candidates for the premium which you have so generously proposed might have been judged tomorrow evening at the last meeting of the Society which will be held before the Christmas Holydays. ${ }^{52}$ The call to Glasgow is irresistible as it is unexpected. I shall certainly, however, return to Edinburgh in the beginning of next week; and you may depend upon it, that at the first meeting of the society which is held afterwards this judgement shall be finally given; that is sometime in the month of january. ${ }^{53}$ As soon as it is given, I shall transmit it to you in the manner you direct; or rather, perhaps, what will be more formal the Secretary of

\footnotetext{
${ }^{49}$ We have not found this letter.

${ }^{50}$ We have not found these two letters.

${ }^{51}$ On November $15^{\text {th }} 1787$ Smith received notice of his election as Lord Rector of Glasgow University. He accepted the offer and told his interlocutor, Principal Davidson, that he travel to Glasgow in December to take up his post (see Smith to Archibald Davidson (Nov 16 ${ }^{\text {th }} 1787$ ) and Mossner \& Ross 1977, 273). Smith took his oath of office on December $19^{\text {th }} 1787$. See Ross $(2010,405-406)$.

52 The session to decide the composition of the committee took place on August $6^{\text {th }} 1787$. The tribunal that would judge the three dissertations presented was composed of Smith, Henry Mackenzie and William Craig. See Transactions of the Royal Society of Edinburgh $(1790,24)$.

${ }^{53}$ See supra, p.5 on this matter.
} 
the Society will transmit it in that manner. ${ }^{54} \mathrm{I}$ have the honour to be, with the highest respect and regard, Sir

Your most obedient and most Humble

Servant

Edinburgh

$16 \operatorname{Dec}^{\mathrm{r}} 1787$.

Adam Smith

\section{Appendix A: Original Letters in French}

\section{Letter $n^{\circ} 1$ : Windischgrätz to Smith, June $20^{\text {th }} 1785$}

Bruxelles le 20 de Juin 1785

\section{Monsieur}

Je dois commencer par vous faire des excuses de vous écrire toujours en francois ; mais quoique je sache assez d'anglois pour comprendre les lettres que vous pouvez me faire l'honneur de m'écrire, je ne le sais pas assez pour l'écrire moi même.

Je ne doute pas Monsieur, que ma réplique du 7 de juin à la lettre que vous m'avez fait l'honneur de m'écrire le 27 de May vous sera parvenue; mais comme mes affaires m'obligent de partir d'ici les prémiers jours de Juillet pour aller dans mes terres de Boheme et d'Allemagne, et qu'il faut absolument, que je publie avant mon départ d'ici mon programme en francois avec des additions, qui, ce me semble, éclaircissent beaucoup la matiere, vous me

\footnotetext{
${ }^{54}$ Tytler sent the result on February $20^{\text {th }} 1788$. This letter was published by Ross \& Raynor $(1997,186-187)$.
} 
pardonnerez, j'espere Monsieur si, au lieu d'attendre votre réponse à ma derniere [lettre], je prends la liberté de m'addresser à vous de nouveau pour vous demander

1) comment je dois m'y prendre pour vous faire parvenir d'ici surement, et de maniere que les frais du transport soient uniquement à ma charge, une cinquantaine d'exemplaires francois de mon programme?

2) comment je dois faire pour faire imprimer dans quelques gazettes de la grande Bretagne l'avis, traduit en Anglois, qui se trouve écrit à la fin de cette lettre?

Permettant aux libraires de Londres et d'Edinbourgh de débiter à leur profit les exemplaires latins, que Mr. Mathews a encore en main, et que je le chargerois de leur remettre, il me semble, que ces libraires pourroient se charger de faire traduire et imprimer cet avis à leur dépens dans les gazettes. Ayez la bonté de me dire Monsieur, je vous prie ce que vous en pensez.

3) si, suposé que vous donniez les mains à l'arrangement que j'ai pris la liberté de vous proposer, c'est-à-dire si la Société Royale d'Edinbourgh consent, comme je l'espere et le désire bien vivement, de concourir au jugement, que je lui ai offert par vous Monsieur, si dans ce cas, dis-je ${ }^{55}$ il vous est égale, que je choisisse telle, ou telle autre Academie d'Allemagne pour concourir à ce jugement avec vos Messieurs, et avec l'Academie des Sciences de Paris du consentement de laquelle je suis sur. Car je dois vous avertir, que l'Academie de Berlin ne veut pas concourir à ce jugement; mais comme il ne sera pas difficile de la remplacer par une autre Academie d'Allemagne, ou en tout cas de la Suisse, et qu'il suffit pour inspirer de la confiance à ceux, qui pourront être tentés de travailler á la solution, de nommer la Société Royale d'Edinbourgh, et l'Academie des Sciences de Paris, en leur indiquant en même tems á qui ils doivent adresser leurs écrits, je puis choisir cette troisieme Academie à loisir, et m'attends que votre réponse définitive Monsieur à ma derniere lettre pour faire imprimer mon

\footnotetext{
55 "si dans ce cas, dis-je" has been added.
} 


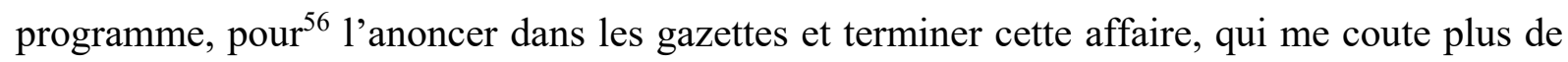
peine et d'embarras, qu'une affaire de ce genre, ce semble, ne devroit couter, si l'on ne savoit pas, que généralement l'on trouve presque toujours plus d'obstacles dans son chemin quand on veut faire le bien, que lorsqu’on forme des projets nuisibles á la Société.

J'attends avec impatience Monsieur vos réponses et les remarques, que vous m'avez fait esperer sur mon problème, je suis sur, qu'elles me donneront beaucoup de lumieres ; mais je ne flatte aussi que mon programme tel qu'il est en francois, éclaircira peut être quelques doutes, que vous pourrez avoir eu à cet égard jusqu'à present. Je doute moi même que le problème soit résolu tout de suite, mais s'il ne l'est pas dans le terme préscrit, je le proposerai de nouveau, et peut être obtiendrons nous dans ce terme des ouvrages, qui nous éclaireront au moins sur la maniere dont il faudra le proposer alors pour esperer une solution complette.

J'ai l'honneur d'être avec la plus haute consideration Monsieur

On a anoncé dans différentes gazettes un programme dans lequel on propose des prix considérables à la solution du problème suivant.

\section{Letter $n^{\circ} 3$ : Windischgrätz to Smith, September $14^{\text {th }} 1785$}

[Address :] a Mr. / Monsieur le docteur Adam / Smith un des comissionaires / surintendants de la douanne d'Ecosse / a Edimbourg / en Ecosse

Vienne le 14 Sept : 1785

\section{Monsieur}

J'ai eu l'honneur de Vous ecrire de Bruxelles, que j'y ai recu au moment de mon départ la lettre du 4 Juillet, que Vous m'avez fait l'honneur de m'y addresser. Je puis vous assurer avec

\footnotetext{
56 "pour" has been added.
} 
sincerité Monsieur, que je suis pénétré de la bonté et de la franchise avec laquelle vous raisonnez sur mon probleme, et si les voyages, que j'ai fait, et des occupations, que j'ai eu depuis mon départ de Bruxelles ne m'en eussent empêchér [sic], je n'eusse pas tardé jusqu'à présent à vous temoigner combien je vous suis obligé.

Je ne doute pas, que les exemplaires francois, de mon programme, que j'ai eu l'honneur de vous faire addresser, il y a plus de deux mois, Vous seront parvenus: en attendant, comme le latin n'étoit qu'une assez mauvaise traduction de l'Allemand, tandis que c'est moi même, qui ai refait tout le programme en francois, en y ajoutant quelques refléxions, et quelques notes, qui sont peut être dignes de fixer votre attention un moment, j'attends avec impatience d'apprendre ce que vous en penséz.

Les refléxions, que Vous faites Monsieur, sont toutes fort profondes, elles prouvent qu'il y a de très grandes difficultés à surmonter pour repondre mon probleme; mais permettez moi de vous le dire Monsieur, elles ne prouvent pas à mes yeux, que ces difficultés soient insurmontables. Les $\S .16$ et 20 . de mon programme francois, et quelques unes des notes, que j’ai ajoutées à cette édition contiennent, ce me semble, des réponses à vos objections.

Supposons cependant un moment, que la solution complette de mon problême soit impossible ; faut-il en conclure, qu'il ne vaut pas même la peine de faire des efforts pour s'en approcher? Si l'on ne tachoit pas dans la pratique de s'approcher de l'exactitude géométrique, quoiqu'on ne puisse pas y atteindre, parviendroit-on à mesurer les espaces ? Je ne crois pas, qu'il y ait une autre marche, qui pourroit diminuer les disputes sur les mots, que celle, que j'indique pout les détruire.

Si j'avois pû croire, que la difficulté seroit beaucoup moins grande, si au lieu d'avoir pour objet toutes les nations, je me fusse contenté de ne me proposer pour but qu'une seule nation ou une seule province, j'eusse pris ce parti avec plaisir, quoique plus humble, comme Vous dites très bien Monsieur, que celui que j'ai pris ; mais il ne me paroit pas possible de faire 
cesser les procès ${ }^{57}$ sur les mots même chez une seule nation, en suivant une autre marche, que celle, que je propose. Il faut toujours prévoir tous les cas, et les prévoyant tous, le problême se trouve résolu pour tous les pais. Ce seroit un avantage, j'en conviens, si l'on ne parvenoit même qu'à perfectionner ce que vous nommez les Style books; mais si l'on se bornoit à ce seul objet, daignez me dire Monsieur, comment il faudroit énoncer le problême dont on demanderoit la solution, pour ne pas être inondé d'ouvrages, dont les auteurs croiroient avoir satisfait au problême, et dont l'utilité seroit cependant fort médiocre, peut être nulle : les termes perfectionner, rendre plus distincts, plus simples, sont vagues, chacun les interprete à sa manière.

Quand on propose un problême à résoudre, il me semble, qu'il faut en même temps traçer la marche, que doivent suivre ceux qui songent à s'en occuper; d'ailleurs il Vous arrive une foule de dissertations dont aucune ne vous mene au but proposé ; car jamais on n'a plus bavardé, qu'on ne bavarde aujourdhui dans tous les pais du monde.

Or, si l'on ne tend pas au but que je préscris, on ne parviendra pas même, ce me semble, à perfectionner beaucoup les Styles Books d'une seule province.

Il se peut, que peu de personnes auront le courage d'entreprendre l'ouvrage que je demande; mais il vaut mieux ne pas avoir d'ouvrages du tout, que d'en avoir qui ne meneroient à rien.

C'est là la manière dont je vois les choses; si Vous daignez y réflechir, peut ètre Vous rapprocherez vous de mon avis, peut être aussi parviendrez vous à m'en faire changer : dans ce cas je serai enchanté d'être éclairé par vous, et d'ajouter par là à la reconnoissance et la haute considération avec laquelle j'ai l'honneur d'être

\section{Monsieur}

\footnotetext{
${ }^{57}$ Preceding "disputes" crossed out.
} 
Votre tres humble et três obeissant serviteur

Le Comte de Windisch-Grätz P.S. Si vous me faites l'honneur de m'ecrir Monsieur, adressez moi toujours, je vous prie vos lettres a Bruxelles.

\section{References}

Abbreviations: SRAP, WFA: State Regional Archives in Plzen, Windischgratz Family Archives.

\section{Smith-Windischgrätz known correspondence}

The letters that have not been found are in square brackets. Beside them, we mention the letters which enable us to deduce their existence.

- Windischgrätz to Smith, 10 May 1785, in Ross \& Raynor (1997, 176-178).

- [Windischgrätz to Smith, before 27 May 1785]. Cf. Smith to Windischgrätz, 27 May 1785.

- Smith to Windischgrätz, 27 May 1785, in Ross \& Raynor (1997, 178-179).

- [Windischgrätz to Smith, 7 June 1785]. Cf. Windischgrätz to Smith, 20 June 1785 and Windischgrätz to Smith, 12 July 1785.

- Windischgrätz to Smith, 20 June 1785, supra, letter $\mathrm{n}^{\circ} 1$. 
- Smith to Windischgrätz, 4 July 1785, supra, letter n 2 (original) and Ross \& Raynor (1997, 79-182) (copy).

- Windischgrätz to Smith, 12 July 1785, in Ross \& Raynor (1997, 182-183).

- Windischgrätz to Smith, 14 September 1785, supra, letter $n^{\circ} 3$.

- [Windischgrätz to Smith, 2 January 1786]. Cf. Smith to Windischgrätz, 17 January 1786.

- Smith to Windischgrätz, 17 January 1786, in Ross \& Raynor (1997, 183-184).

- Windischgrätz to Smith, 12 July 1787, in Ross \& Raynor (1997, 184-185).

- [Windischgrätz to Smith, before 9 November 1785]. Cf. Smith to Windischgrätz, 16 December 1787 and Windischgrätz to Smith, 30 December 1787.

- [Windischgrätz to Smith, 9 November 1787]. Cf. Smith to Windischgrätz, 16 December 1787 and Windischgrätz to Smith, 30 December 1787.

- Smith to Windischgrätz, 16 December 1787, supra, letter $n^{\circ} 4$.

- Windischgrätz to Smith, 30 December $1787^{58}$, in Ross \& Raynor $(1997,185)$.

- Smith to Windischgrätz, 26 January 1788, in Ross \& Raynor (1997, 186).

\section{Other references}

“Rapport sur le Programme de Windischgrätz", Nouveaux mémoires de l'Académie royales des sciences et belles-lettres [for 1785], Berlin: G. J. Decker, 1787: 36-43.

Baker, K. M. (1975). Condorcet, From Natural Philosophy to Social Mathematics. Chicago; London: University of Chicago press.

Bru B. \& Crépel P. (1994). Condorcet, Arithmétique politique - textes rares ou inédits, 17671789. Paris: INED.

${ }^{58}$ Ross \& Raynor (1997, p. 185) mistakenly dates this letter as of “[? Octobre] 1787”. It is not October because this letter is a reply to the Smith's letter of December 16th 1785 published here. The confusion undoubtedly comes from an "X" written by Windischgrätz in order to designate December, and not the tenth month of the year, i.e. October. 
Condorcet, M.-J.-A.-N. Caritat de (June 1785). Corrections sur la traduction française du Programme de Windischgrätz (June 1785), SRAP, WFA, nº 959 , file ${ }^{\circ}$ XIII (unnumbered sheets).

—. (1785). "Lettre au Journal de Paris". In Condorcet, Arithmétique politique - textes rares ou inédits, 1767-1789, edited by B. Bru \& P. Crépel, 534-535. Paris: INED.

Condorcet, M.-J.-A.-N. Caritat de, Borda, J.-Ch., Duséjour, A.-P., Laplace, P.-S. (1785), Rapport [sur la proposition de Windischgrätz de charger l'Académie des sciences d'être juge de son prix]. In Condorcet, Arithmétique politique - textes rares ou inédits, 17671789, edited by B. Bru \& P. Crépel, 532-534. Paris: INED.

Crépel, P. \& Rieucau, N. (2005). “Condorcet's Social Mathematic - A Few Tables”, Social Choice and Welfare 25(2-3): 243-285.

Daston, L. (1988). Classical Probability in the Enlightenment. Princeton, N.J.: Princeton University Press.

Dow, A. (1984). “The Hauteur of Adam Amith: An unpublished letter from James Anderson of Monkshill”, Scottish Journal of Political Economy 31(3): 284-285.

Extrait des registres de l'Académie royale des sciences du 7 février 1789 communiqué par Condorcet à Windischgrätz, SRAP, WFA, n931 (unnumbered piece).

Ford, J. D. (2007). Law and Opinion in Scotland during the Seventeenth Century. Oxford: Hart Publishing Ltd.

Grecenkova, M. (2002). "Le réseau épistolaire scientifique européen de Joseph Nicolas de Windischgrätz", La Plume et la Toile, collected by P.-Y. Beaurepaire, 289-305. Arras: Artois Presses Université.

- (2003). "Les formules générales de tous les contrats imaginables : un débat dans la République des Lettres sur la réforme de la société", Studies on Voltaire and the Eighteenth Century 2003:01: 271-289. 
—. (2006). "Windischgrätz et Condorcet : une collaboration et une correspondance sur les projets des Lumières". In Adelige Ausbildung. Die Herausforderung der Aufklärung und die Folgen, edited by I. Cerman, 279-297. Munich: Martin Meidenbauer.

—. (2007). La noblesse de la monarchie des Habsbourg au cœur de la République des Lettres européenne : le cas de la relation entre Windischgrätz et Condorcet", Revue des études slaves 78: $451-467$.

—. (2009). "Windischgrätz and Condorcet: A Tale of One Enlightenment Project", The Czech Historical Review 107(3): 569-598.

Lock, F. P. (2006). “An Unpublished Letter from Adam Smith to Sir John Macpherson”, The Scottish Historical Review 85(219), Part 1: 135-137.

McCloskey, D. N. (2008). "The Last of the Former Virtue Ethicists", History of Political Economy 40(1): 43-71.

Mossner, E. C. \& Ross, I. S. (1977). The Correspondence of Adam Smith, $2^{\text {nd }}$ ed., (Glasgow Edition of the Works and Correspondence of Adam Smith, 1977, Vol. 6). Indianapolis: Liberty Fund.

Paganelli, M. P. (2009). “Approbation and the Desire to Better One's Condition in Adam Smith: When the Desire to Better One's Conditions does not Better One' s Condition and Society's Condition...", Journal of the History of Economic Thought 31(1): 79-92.

Raphael, D. D., Raynor, D. \& Ross, I. S. (1990). “"This very awkward affair”: an entanglement of Scottish professors with English lords", Studies on Voltaire and the Eighteenth Century 278: 437-438.

Ross, I. S. (1974). "Preface [to $1^{\text {st }}$ ed.]". In The Correspondence of Adam Smith, $2^{\text {nd }}$ ed., edited by E. C. Mossner \& I. S. Ross (Glasgow Edition of the Works and Correspondence of Adam Smith, 1977, Vol. 6), 7-10. Indianapolis: Liberty Fund.

-. (2010). The Life of Adam Smith, $2^{\text {nd }}$ ed. Oxford: Oxford University Press. 
Ross, I. S. \& Raynor, D. (1997). “Adam Smith and Count Windisch-Grätz: new letters”, Studies on Voltaire and the Eighteenth Century 358: 171-187.

Sitzungsprotokolle 1746-1786, in Online-Ausgabe der Sitzungsprotokolle 1746-1786, Archiv der Berlin-Brandenburgischen Akademie der Wissenschaften.

Smith A. (1762-3). Lectures on Jurisprudence, edited by R. L. Meek, D. D. Raphael \& P. G. Stein (Glasgow Edition of the Works and Correspondence of Adam Smith, 1976, Vol. 5). Indianapolis: Liberty Fund, 1987.

-. (1790). The Theory of Moral Sentiments, edited by D. D. Raphael \& A. L. Macfie (Glasgow Edition of the Works and Correspondence of Adam Smith, 1976, Vol. 1). Indianapolis: Liberty Fund, 1987.

-. (1795: posth.), On the Nature of that Imitation which takes place in what are called the Imitative Arts (in Essays on Philosophical Subjects, edited by J. Black \& J. Hutton, 131178. London: T. Cadel and W. Davis.

Transactions of the Royal Society of Edinburgh, Vol 1, Edinburgh: J. Dickson, 1788; Vol. 2, Edinburgh: J. Dickson et T. Cadell, 1790.

Windischgrätz, Joseph-Nicolas de (1785), Programme par lequel on propose aux savans de toutes les nations de résoudre le problême suivant [...] : "trouver pour toutes les espèces possibles d'écrits, par lesquels ont peut transférer [...] sa propriété [...], des formulaires construits de manière, qu'il suffise, pour exprimer chaque cas particulier possible, de remplir les espaces vides [...] [et] dont les expressions tant variables qu'invariables, c'està-dire tout l'énoncé, soit aussi peu susceptible de doute et d'interprétations que la géométrie." [...], Paris: Mérigot. 